2017-01-18

Predicting copper speciation in

estuarine waters Is dissolved organic

carbon a good proxy for the presence of organic ligands?

\title{
Pearson, HBC
}

http://hdl.handle.net/10026.1/8268

10.1021/acs.est.6b05510

Environmental Science \& Technology

American Chemical Society (ACS)

All content in PEARL is protected by copyright law. Author manuscripts are made available in accordance with publisher policies. Please cite only the published version using the details provided on the item record or document. In the absence of an open licence (e.g. Creative Commons), permissions for further reuse of content should be sought from the publisher or author. 
Accepted journal article in Environmental Science and Technology - please refer to following DOI for full content:

DOI: 10.1021/acs.est.6b05510

\section{Predicting copper speciation in estuarine waters - Is dissolved organic carbon a good proxy for the presence of organic ligands?}

Holly B.C. Pearson ${ }^{a}$, Sean D.W. Comber ${ }^{a^{*}}$, Charlotte Braungardt ${ }^{a}$ and Paul J. Worsfold ${ }^{a}$

a Biogeochemistry Research Centre, University of Plymouth, Plymouth, Devon, UK, PL4 8AA.

* Corresponding author: email: sean.comber@plymouth.ac.uk tel: $+44(0) 1752585974$

\section{Abstract}

A new generation of speciation-based aquatic environmental quality standards (EQS) for metals have been developed using models to predict the free metal ion concentration, the most ecologically relevant form, to set site-specific values. Some countries such as the UK have moved towards this approach by setting a new estuarine and marine water EQS for copper, based on an empirical relationship between copper toxicity to mussels (Mytilus sp.) and ambient dissolved organic carbon (DOC) concentrations. This assumes an inverse relationship between DOC and free copper ion concentration owing to complexation by predominantly organic ligands. At low DOC concentrations the new EQS is more stringent, but above 162 $\mu \mathrm{M} D O C$ it is higher than the previous value. However, the relationship between DOC and copper speciation is poorly defined in estuarine waters. This research discusses the influence of DOC from different sources on copper speciation in estuaries and concludes that DOC is not necessarily an accurate predictor of copper speciation. Nevertheless, the determination of ligand strength and concentrations by Competitive Ligand Exchange Adsorptive Cathodic Stripping Voltammetry enabled the prediction of the free metal ion concentration within an order of magnitude for estuarine waters by using a readily available metal speciation model (Visual MINTEQ).

Keywords: Copper, speciation, estuarine waters, dissolved organic carbon, ligands, modelling 
38 The importance of chemical speciation is widely recognised in the scientific and regulatory community, where physico-chemical characteristics control solubility, reactivity, biological availability and toxicity in the environment. ${ }^{1,2}$ The most toxic form of copper $(\mathrm{Cu})$ in natural waters is the free metal ion $\left[\mathrm{Cu}^{2+}\right]$ which can also be incorporated into the "labile" fraction, consisting of the free hydrated Cu cation plus weakly bound (largely inorganically complexed) $\mathrm{Cu}^{3}$ Water quality parameters, such as major ion concentrations, $\mathrm{pH}$ and organic chelating agents (ligands) associated with dissolved organic carbon (DOC) are recognised as quantifiable parameters that significantly influence metal toxicity, through competitive binding by other major cations at reactive sites, ${ }^{3}$ lowered ionic activity of the metal, ${ }^{4}$ or complexation of the metal by the organic ligands. Increasing DOC concentrations have been shown to mitigate the toxic effects of $\mathrm{Cu}$ in organisms. ${ }^{5}$

In the USA, speciation-based approaches to $\mathrm{Cu}$ regulation in fresh water have been established since 2003 using the Biotic Ligand Model (BLM). ${ }^{6,7}$ The BLM combines thermodynamic equilibrium calculations of free metal ion concentrations generated by development of the Free Ion Activity Model (FIAM) using information on ambient water quality including at its most basic level, calcium concentrations (hardness), $\mathrm{pH}$ and DOC, with ecotoxicological endpoints to predict toxicity to classes of organisms or to set sitespecific water quality standards. ${ }^{6,7}$ The complex chemistry within estuarine systems and lack of research slowed the development of BLMs for estuarine and coastal waters. Recently, a number of studies have shown that $\mathrm{Cu}$ toxicity can be predicted: model development is underway predicting the fate of $\mathrm{Cu}$ in US harbours ${ }^{8}$ and a BLM has been developed for marine waters. ${ }^{9}$

Although some studies addressed the complexation of metals, such as $\mathrm{Cu}$, in saline waters, ${ }^{10,11}$ data are limited and rarely combine other potentially important parameters such as DOC concentration and ligand characterisation with measurements of speciation. Currently no saline water BLM has been developed for the EU regulatory framework. The latest UK environmental quality standard (EQS) for $\mathrm{Cu}$ in saline waters has been revised under the Water Framework Directive (WFD) does, however recognise the bioavailabilitycontrolling role of organic ligands present within the DOC pool. ${ }^{12}$ The new Cu EQS is based on a species sensitivity distribution of toxicity data for predominantly marine organisms (salinity greater than 20). The generic EQS generated using this approach (applicable to all estuarine and coastal waters) is converted to a site-specific EQS based on the measured ambient DOC concentration as a surrogate for copper complexation (Figure S1 in the 
applicable to estuaries and coastal waters across all salinities is based on observed mussel (Mytilus galloprovincialis) toxicity data across a range of DOC concentrations (Figure S2). ${ }^{12}$ Up to a DOC concentration of $83 \mu \mathrm{M}\left(1 \mathrm{mg} \mathrm{C} \mathrm{L}^{-1}\right)$ the Cu EQS is fixed at $59 \mathrm{nM}\left(3.8 \mu \mathrm{g} \mathrm{Cu} \mathrm{L^{- }}\right.$ $\left.{ }^{1}\right)$. The EQS increases linearly above $\mathrm{DOC}=83 \mu \mathrm{M}\left(1 \mathrm{mg} \mathrm{C} \mathrm{L}^{-1}\right)$ to a point where, above $\mathrm{DOC}=162 \mu \mathrm{M}\left(1.95 \mathrm{mg} \mathrm{C} \mathrm{L}^{-1}\right)$, the site specific Cu EQS is more relaxed than the previous fixed value of $78 \mathrm{nM} \mathrm{Cu}$. If DOC concentrations reach $475 \mu \mathrm{M}\left(5.71 \mathrm{mg} \mathrm{C} \mathrm{L}^{-1}\right)$ the $\mathrm{Cu} E Q S$ is twice the previous value.

The EQS derivation therefore relies on the assumption that DOC is 'protective' which is well established under laboratory conditions using DOC sources such as humic and fulvic acids. ${ }^{13}$ Figure S2 shows the relationship between DOC and EC50 (the concentration that negatively affects $50 \%$ of the tested population) for Mytilus. However, increased data scatter above $500 \mu \mathrm{M}\left(6 \mathrm{mg} \mathrm{L}^{-1}\right) \mathrm{DOC}$ is evident. For example, the EC50 varies by up to a factor of 5 at ca. $500 \mu \mathrm{M} \mathrm{DOC}$, and DOC varies by up to a factor of 3 for a given EC50 of ca. $500 \mu \mathrm{M}$ $\mathrm{Cu}$. Although the EQS derivation uses the same experimental data expressed as EC10 rather than EC50, the same variability in DOC vs toxicity response is observed. This scatter originates in the variability of ecotoxicological data within and across experiments and the fact that not all DOC contributes to $\mathrm{Cu}$ complexation. The latter is reflected in existing computational models for $\mathrm{Cu}$ toxicity, where various correction factors are applied to observed DOC concentrations to account for the contribution of organic ligands to $\mathrm{Cu}$ complexation. This is described as 'active DOC' in the Windermere Humic Aqueous Model (WHAM) models, ${ }^{14}$ 'humic acid content' in $\mathrm{BLMs}^{3}$ and is converted into ligands via algorithms such as the NICA-Donnan, Gaussian or Stockholm Humic Models in Visual MINTEQ. ${ }^{15}$ The effectiveness of these assumptions in characterising the $\mathrm{Cu}$ complexation within saline waters is variable and often leads to over prediction of free $\mathrm{Cu}$ ion concentrations $\left(\left[\mathrm{Cu}^{2+}\right]\right)$, particularly at low $\mathrm{Cu}$ concentrations. ${ }^{14}$ Although this is conservative, a lack of agreement between predicted and actual values suggests improvements in the existing models are possible which would further strengthen the application of BLMs for saline waters BLMs. Studies generally show weak relationships between $\mathrm{Cu}$ complexation capacity $\left(\left[\mathrm{L}_{x}\right]\right)$ and DOC concentrations measured in saline waters (Figure 1), ${ }^{11,16-19}$ unless samples were taken across a limited range of salinities and/or restricted to a specific ligand strength, typically derived from a single source such as river humic and fulvic acids. ${ }^{16,18}$ It is important to note that in all cases the organic ligand complexation capacities are in the order of 1 to $100 \times 10^{-9}$

$104 \mathrm{M}$ of $\mathrm{Cu}$ compared with DOC concentrations in the $1-100 \times 10^{-6} \mathrm{M}$ range. In other words, 105 


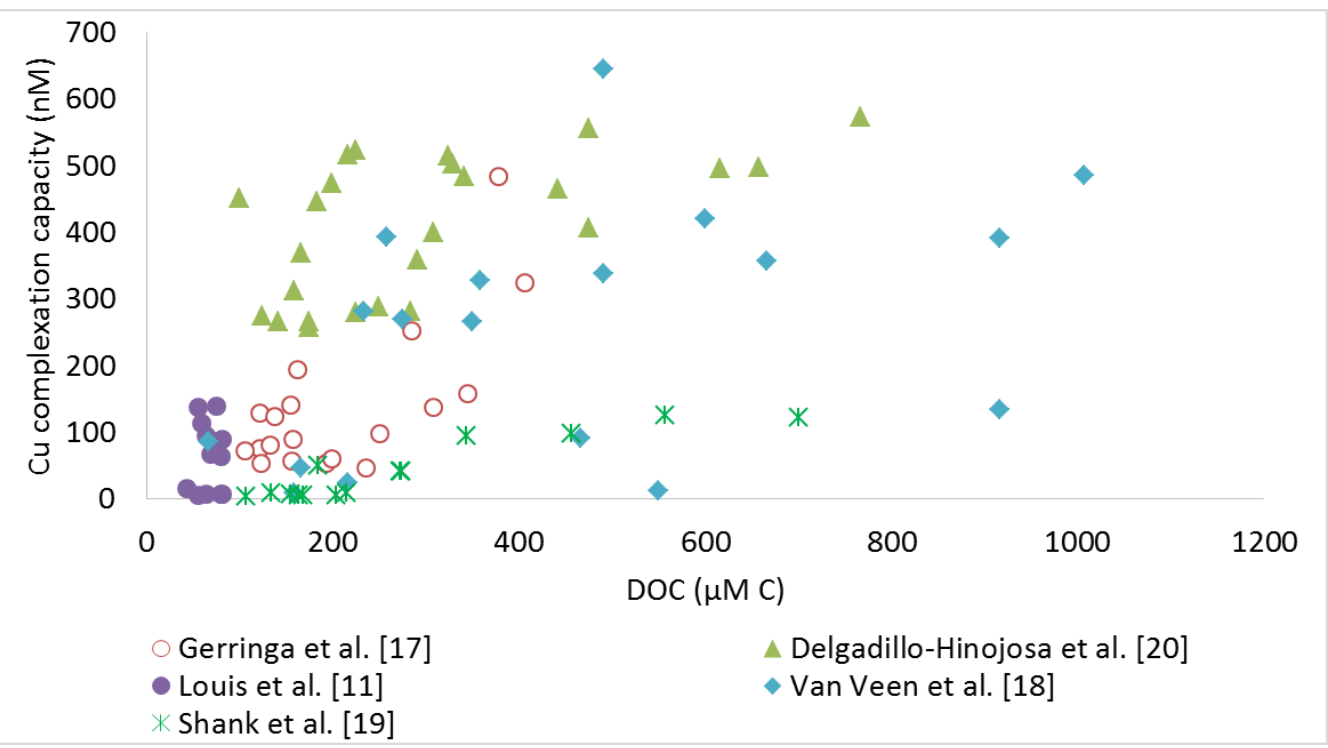

107 Figure 1. Complexation capacity for Cu vs. DOC (data from ${ }^{11,17-20}$ ).

109 Are there better ways to capture the effects of metal complexation by organic ligands in 110 estuarine waters than using DOC as a surrogate for bioavailability? Most existing research in 111 freshwater has focussed on the complexation of $\mathrm{Cu}$ by humic and fulvic acids, but these 112 materials, derived mainly from breakdown of terrestrially derived organic matter are, while 113 important, ${ }^{4}$ not the only source of DOC to the estuarine environment. Wastewater Treatment 114 Works (WwTW) effluent contains high concentrations of DOC (in excess of $833 \mu \mathrm{M}(10 \mathrm{mg}$ $\left.\left.115 \mathrm{C} \mathrm{L}^{-1}\right)\right)$, ${ }^{20}$ comprising natural and synthetic ligands capable of strongly complexing metals. ${ }^{17,21}$ 116 Estuaries are habitats of high primary productivity and ligand production through cell lysis 117 after phytoplankton blooms often exceeding 1000's of cells per $\mathrm{mL}$ and proteinaceous 118 exudates of macrophytes. ${ }^{22,19}$

119 This study seeks relationships between the different forms of $\mathrm{Cu}$ within an estuarine 120 environment subject to varying salinity, DOC concentration and potential organic ligand 121 sources. A degree of in situ organic matter source characterisation was performed using 122 established fluorimetric techniques to determine humification and biological indices (Section 123 S2.5), to seek improved relationships between $\mathrm{Cu}$ speciation and potential organic ligands. 124 This was achieved by collecting samples in different seasons between 2013 and 2015 from 125 the Tamar; a temperate, macrotidal estuary in SW England. This estuary is subject to inputs 126 of organic ligands from sources including WwTW effluent, natural breakdown of organic 127 matter and primary production (Figure 2). Stripping voltammetry was used to determine 128 operationally defined Cu-complexing organic ligand concentrations (complexation capacity, $129\left[\mathrm{~L}_{x}\right]$ ), stability constants (Log $K$ ) of Cu-organic ligand complexes, $\left[\mathrm{Cu}^{2+}\right]$ and labile $\mathrm{Cu}$ 
130 concentrations. Copper speciation data have been interpreted in combination with measured 131 DOC concentrations and characteristics (indices), which can indicate the presence of humic 132 and fulvic acids and/or in situ biologically derived organic compounds. In order to establish if 133 the toxic $\left[\mathrm{Cu}^{2+}\right]$ fraction can be successfully predicted for the samples collected, a freely 134 available program, Visual MINTEQ (VM) was used to calculate $\left[\mathrm{Cu}^{2+}\right]$ in each sample in two 135 modes: (i) using the "default" NICA-Donnan humic complexation model to convert measured 136 DOC concentration into Cu-complexing organic ligand concentrations and (ii) using the 137 measured $\left[\mathrm{L}_{x}\right]$ and log $K$ for two ligand strengths determined by stripping voltammetry with 138 complexation capacity titrations. The results allowed an evaluation of the effectiveness of 139 DOC as a proxy for predicting $\mathrm{Cu}$ speciation in saline waters and of the accuracy of in-built 140 model algorithms for calculating the distribution of $\mathrm{Cu}$ species. The combination of measured 141 environmental $\mathrm{Cu}$ speciation data, DOC characterisation and modelling carried out in this 142 study provides vital data and critical analysis to support on-going BLM development for 143 saline waters. 


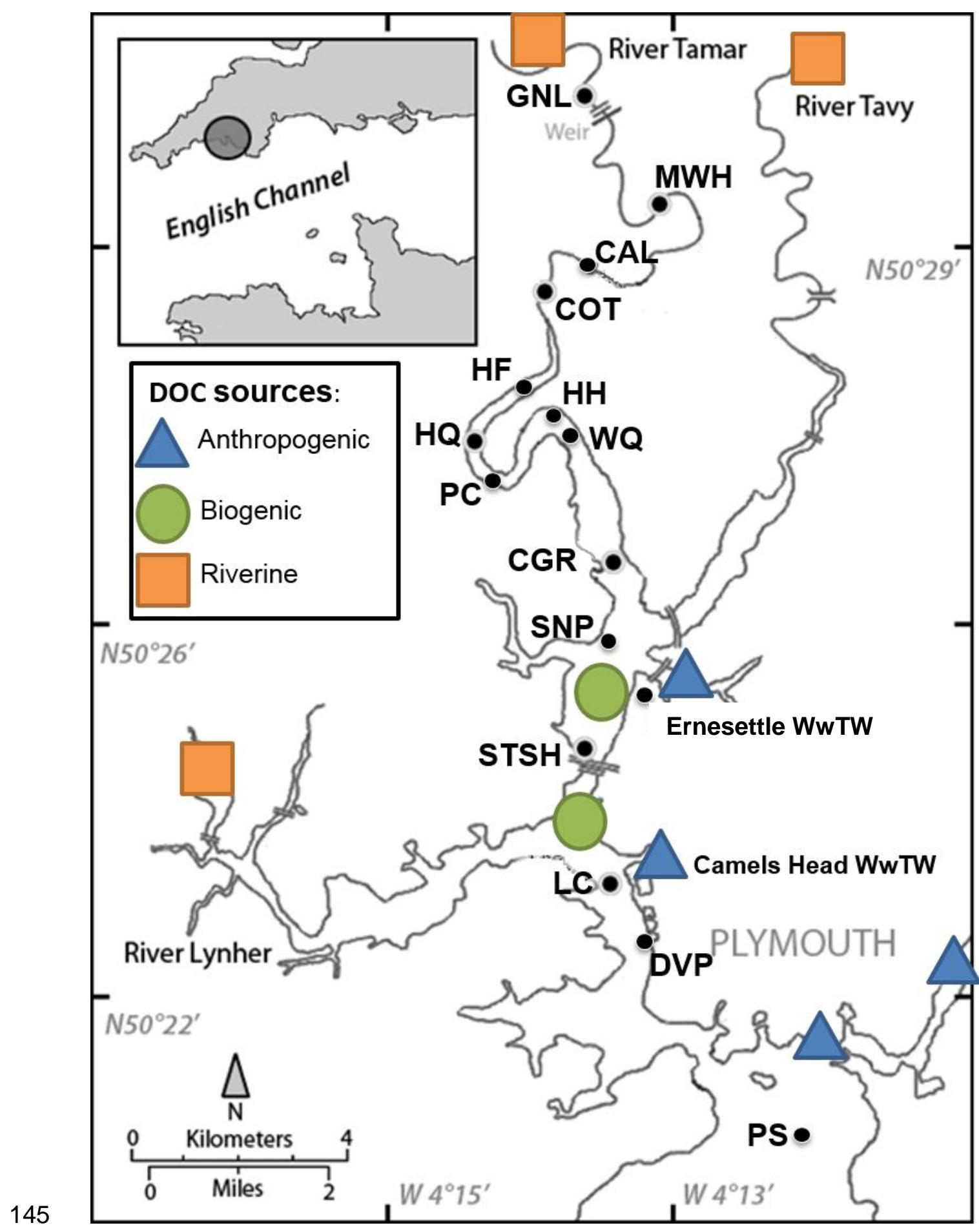

Figure 2. Map of the Tamar Estuary, UK, with sampling station locations. Abbrev: PS Plymouth Sound; DVP Devonport; LC Lynher Confluence; STSH Saltash; SNP South of Neal Point; CGR Cargreen; HF Haye Farm; WQ Weir Quay; HH Holes Hole; PC Pentillie Castle; HQ Halton Quay; COT Cotehele; CAL Calstock; MWH Morwellham Quay; GNL Gunnislake; WwTW Waste water treatment works. Potential DOC sources are marked with coloured symbols. Outline derived from Ordnance Survey (1:50000, 2001). Insert: Made with Natural Earth. Free vector and raster map data @ naturalearthdata.com. 


\section{EXPERIMENTAL}

\subsection{Tamar catchment and sampling sites}

160 The Tamar Estuary extends $16 \mathrm{~km}$ from Gunnislake Weir to the English Channel via 161 Plymouth Sound, with the Lynher and Tavy rivers being significant tributaries near its mouth 162 (Figure 2). The catchment area is $1700 \mathrm{~km}^{2}$ and its length is close to the average for U.K. 163 estuaries. ${ }^{23}$ The upper estuary receives inputs of contaminants, such as $\mathrm{As}, \mathrm{Cu}, \mathrm{Zn}$ and $\mathrm{Pb}$, 164 from unconstrained mining waste from historic mining activities, particularly in the vicinity of 165 Gunnislake, where the tidal influence terminates above a weir. ${ }^{24}$ The DOC in the river inputs from the Tamar, Lynher and Tavy are likely to be dominated by humic and fulvic acids from degradation of vegetation and run-off from upstream agricultural and moor land. ${ }^{25}$ Effluent from WwTW at Ernesettle and Camels Head (Figure 2) with an approximate combined discharge of 30 million litres per day also enters the estuary in the higher salinity region, introducing metals, as well as natural and synthetic complexing ligands. ${ }^{21}$ From the confluence with the Lynher (denoted as site LC in Figure 2), intense phytoplankton blooms occur through the spring and summer months as visibly seen in the water column in the July 2013 and 2014 samples as part of this work and previously. ${ }^{26}$ Anthropogenically derived contamination originating from the naval dockyard and urbanised areas near the mouth of the estuary impacts on coastal water quality. ${ }^{27}$ Sampling sites (between 5 and 8 depending on tidal regime) along the length of the estuary were chosen to provide a range of salinities as well as a variety of known metal and ligand sources (Figure 2). Sampling was carried out on five occasions between July 2013 and February 2015, covering different seasons with variations in river flow, salinity, and the presence of phytoplankton blooms during the spring and summer months.

\subsection{Chemicals and reagents}

All chemicals used were of analytical grade or higher, and ultrahigh purity (UHP) water (Elga Process Water, resistivity $=18.2 \mathrm{M} \Omega \mathrm{cm}$ ) was used for all applications. Hydrochloric acid (6 M, ROMIL SpA) was used throughout. Element reference solutions (ROMIL PrimAg) were used to prepare $\mathrm{Cu}$ standards to a concentration of $1 \mu \mathrm{M}$. A $1 \mathrm{M}$ stock solution of HEPES buffer was prepared from N-hydroxyethylpiperazine-N'-2'-ethanesulphonic acid (Biochemical grade, BDH Laboratory Supplies). The $\mathrm{pH}$ of the HEPES buffer was adjusted to 7.8 using ammonium hydroxide solution (ROMIL SpA). A $0.05 \mathrm{M}$ stock solution of salicylaldoxime (SA; $98 \%$ Acros Organics) was prepared by dissolving in $0.5 \mathrm{~mL} 6 \mathrm{M} \mathrm{HCl}$ and making up to 30 $\mathrm{mL}$ with UHP water. This was diluted daily to make a working stock solution of $0.01 \mathrm{M} \mathrm{SA}$ 
191

when used for Cu complexation capacity titrations (CCT) at concentrations of 2 and $10 \mu \mathrm{M}$, and for determinations of $\left[\mathrm{Cu}_{\llcorner A B}\right]$ and $\left[\mathrm{Cu}_{T D}\right]$ at $25 \mu \mathrm{M}$.

\subsection{Sampling and sample handling protocol}

Section A1 (SI) details the sampling protocol. All sampling and filtration equipment was acid washed and rinsed with UHP water prior to use. Samples for dissolved $\mathrm{Cu}$ were filtered through acid washed track-edged $47 \mathrm{~mm}<0.45 \mu \mathrm{m}$ Nuclepore (Whatman) membrane filters using acid washed Nalgene filtration units. Samples for DOC were filtered within $24 \mathrm{~h}$ of collection, acidified to ca. $\mathrm{pH}$ 2, and refrigerated in glass vials. Samples for the determination of total dissolved $\left(\left[\mathrm{Cu}_{\mathrm{TD}}\right]\right)$ and labile $\left(\left[\mathrm{Cu}_{\mathrm{LAB}}\right]\right) \mathrm{Cu}$ concentrations were refrigerated and analysed within $48 \mathrm{~h}$ at ambient room temperature. Samples for the determination of metal complexation capacity were frozen for later analysis.

\subsection{Analytical methods, procedures and calculations}

All dissolved $\mathrm{Cu}$ analysis was undertaken by competitive ligand exchange adsorptive cathodic stripping voltammetry (CLE-AdCSV, Section S2, SI). Labile $\mathrm{Cu}$ is operationally defined as the fraction of $\mathrm{Cu}$ that will form a complex with the added ligand salicylaldoxime $(\mathrm{SA})$ at a set concentration. This includes $\left[\mathrm{Cu}^{2+}\right]$ plus $\mathrm{Cu}$ held in weak complexes (e.g. bound by inorganic and weak organic ligands) that are substituted by the SA ligand within the timeframe of the determination. [ $\mathrm{Cu}_{\mathrm{LAB}}$ ] was calculated from triplicate voltammetric scans (RSD $\leq 5 \%$ ) conducted on duplicate aliquots of sample (RSD $\leq 10 \%$ ).

Prior to $\left[\mathrm{Cu}_{\mathrm{TD}}\right]$ determinations, acidified samples were UV irradiated in the presence of hydrogen peroxide (final concentration of $15 \mathrm{mM}$ ). Sample $\mathrm{pH}$ was raised to ca. 6 with ammonia solution (SpA, ROMIL) prior to adding HEPES and SA for analysis using the same voltammetric procedure as for labile $\mathrm{Cu}$. Certified reference materials (CRMs) were included with each batch of samples. Recoveries were between 89 and $112 \%$, with a typical precision of $\leq 10 \% \mathrm{RSD}$. The limit of detection (LOD) was typically $0.33 \mathrm{nM}$ Cu using maximum drop size, stirring speed and $60 \mathrm{~s}$ deposition.

Complexation capacity titrations (CCT) were performed at a fixed $\mathrm{pH}$ of 7.8 using HEPES buffer (at a final concentration of $10 \mathrm{mM}$ in the $10 \mathrm{~mL}$ sample) at two competitive ligand strengths, using $\mathrm{SA}$ at 2 and $10 \mu \mathrm{M}$ to provide detection windows $\left(\log a_{\text {CuSA }}=3.01-4.59\right.$ and $3.03-5.29$, respectively), consistent with $\mathrm{Cu}$ ligand strengths previously investigated in the estuarine environment. Aliquots of sample were spiked with 10 incremental additions of $\mathrm{Cu}$ to a final concentration of ca 1.5 orders of magnitude greater than $\left[\mathrm{Cu}_{\mathrm{TD}}\right]$ in the sample and allowed to equilibrate overnight. Each sample aliquot was determined by CLE-AdCSV using analytical parameters provided in Section A2. Peaks for each voltammetric sweep were typically in the 5 to $100 \mathrm{nA}$ range. 
Duplicate titrations were carried out on all samples at each SA concentration, with triplicate voltammetric sweeps carried out on each aliquot to generate a mean peak height for each Cu addition. Data were transformed using a method reported by van den Berg/Ruzic ${ }^{28,29}$ to quantify the $\left[\mathrm{L}_{x}\right]$ (in $\mathrm{nM}$ ), the conditional stability constant (log $K_{\text {CuL }}$ ) of 230 the Cu-natural ligand complexes and $\left[\mathrm{Cu}^{2+}\right]$. Owing to the very low concentration of $231\left[\mathrm{Cu}^{2+}\right]$ in natural waters (typically $10^{-13}$ to $10^{-11} \mathrm{M}$ ), for the purpose of displaying the data and showing trends, the negative logarithm of the $\mathrm{Cu}$ concentration has been taken and concentrations (rather than activity) shown as $\mathrm{pCu}^{2+}$.

DOC was determined using high temperature catalytic combustion (Shimadzu TOC V analyser). ${ }^{30}$ A marine water CRM (Florida Strait $700 \mathrm{~m}$ depth) was determined with each batch of samples and the LOD for DOC determination was $4 \mu \mathrm{M}$. Characterisation of the DOC was undertaken using 3-D fluorimetry with a Hitachi F-4500 FL spectrophotometer. Calibration standards were diluted into UHP using Sigma Aldrich humic acid $(55.1 \%$ C; Sigma Aldrich, UK) and Nordic aquatic fulvic acid reference material supplied by the International Humic Substances Society (45\% C).

\subsection{Thermodynamic equilibrium speciation calculations}

243 All calculations were undertaken using Visual MINTEQ version $3.1^{15}$, a freeware chemical equilibrium model for the calculation of metal speciation, solubility equilibria, sorption etc. for natural waters. It combines descriptions of sorption and complexation reactions on a Windows platform and has the capacity for users to input new ligands (in this case $\log K_{C u L_{x}}$ values and ligand concentrations derived from the CCT field data at two separate artificial ligand strengths) into its database. Input cation and anion concentrations were generated using an ion-pairing model ${ }^{31}$ (see section S2.1) using the Gunnislake freshwater sample composition from this survey and available Environment Agency data ${ }^{32}$ as well as reported coastal water data ${ }^{33}$ as endmembers.

VM was used to predict $\left[\mathrm{Cu}^{2+}\right]$ using the following input values (further default parameters in section S3):

1) Major ion concentrations $\left(\mathrm{Na}^{+}, \mathrm{Mg}^{2+}, \mathrm{K}^{+}, \mathrm{H}^{+}, \mathrm{Sr}^{2+}, \mathrm{Cl}^{-}, \mathrm{Br}^{-}, \mathrm{SO}_{4}{ }^{2-}, \mathrm{F}^{-}\right)$generated from conservative mixing of Tamar freshwater (mean concentrations from Gunnislake sample from present surveys and available Environment Agency data) ${ }^{32}$ and sea water $^{33}$ end member data obtained from the ion-pairing seawater model (see section S2.1)

2) $\left[\mathrm{Cu}_{\mathrm{TD}}\right]$ measured as part of this work

3) Ligand concentrations: 
a. Measured as part of this work using 2 and $10 \mu \mathrm{M}$ SA with their accompanying conditional stability constants

b. Ligands generated within VM 3.1 using measured DOC concentrations from these surveys (Table S2) and the NICA-Donnan model for generating complexing ligands based on default assumptions that all active DOM is fulvic acid with no humic acid being 'active' in complexing Cu. Furthermore, 82.5\% of DOC is assumed to be "generic fulvic acid" with a C content of $50 \%$; giving a DOM to DOC ratio of 1.65 (see Section S2 of the SI)

The calculations were run at $\mathrm{pH} 7.8$ and the default temperature of $15{ }^{\circ} \mathrm{C}$, using Davies method for activity correction, with no other organic ligands present and assuming thermodynamic equilibrium. Sensitivity analyses (results not shown) performed by running VM calculations at the natural sample $\mathrm{pH}$ and temperature showed negligible difference in calculated speciation using either approach.

\section{RESULTS AND DISCUSSION}

\subsection{Measured Cu speciation within estuarine waters}

The Tamar estuary features a tidally induced, strong and well defined turbidity maximum zone (TMZ) between 0 and 10 salinity $^{23}$ and the extensive mudflats in midestuary are contaminated as a result of the mining legacy within the catchment. ${ }^{24}$ Both impact on overlying water chemistry and $\mathrm{Cu}$ speciation over the course of tidal cycles.

\section{The full set of $\left[\mathrm{Cu}_{T D}\right]$ and $\left[\mathrm{Cu}_{\llcorner A B}\right]$ for all the surveys are displayed in Table $\mathrm{S}$} 2 of the SI. The [CuTD] ranged from 8 to $189 \mathrm{nM}$ (Figure 3), with highest concentrations invariably observed in the freshwater sample taken at Gunnislake, reflecting the continuous contamination emanating from historic mine sites. ${ }^{24}$ These concentrations are comparable with those found in previous studies of the Tamar. ${ }^{34} \mathrm{~A}$ plot of $\left[\mathrm{Cu}_{\mathrm{TD}}\right]$ versus salinity shows non-conservative behaviour as fresh and saline waters mix at low salinities. This was likely a result of (i) loss of metal from the dissolved phase owing to a combination of sorption to suspended solids within the $\mathrm{TMZ}^{35}$ and/or (ii) precipitation reactions associated with amorphous Fe oxyhydroxides and flocculation of colloidal material. ${ }^{36}$ 
The increase of $\left[\mathrm{Cu}_{T D}\right]$ at mid to high salinity in July 2013 and April 2014 is potentially attributable to additional inputs from tributaries contaminated with historical mine waste (Lynher, Tavy) ${ }^{24}$ or mobilisation of metal from bed sediment during tidal pumping. ${ }^{35}$ The combined effluent input to the lower estuary from Plymouth WwTW works is approximately $72 \times 10^{6} \mathrm{~L} \mathrm{~d}^{-1}$, with median copper concentrations of $5.6 \mu \mathrm{g} \mathrm{L}^{-1}$ reported for English WwTW effluents ${ }^{20}$. This equates to approximately $400 \mathrm{~g}$ of $\mathrm{Cu}$ per day, which, with dilution, is unlikely to impact on observed concentrations.
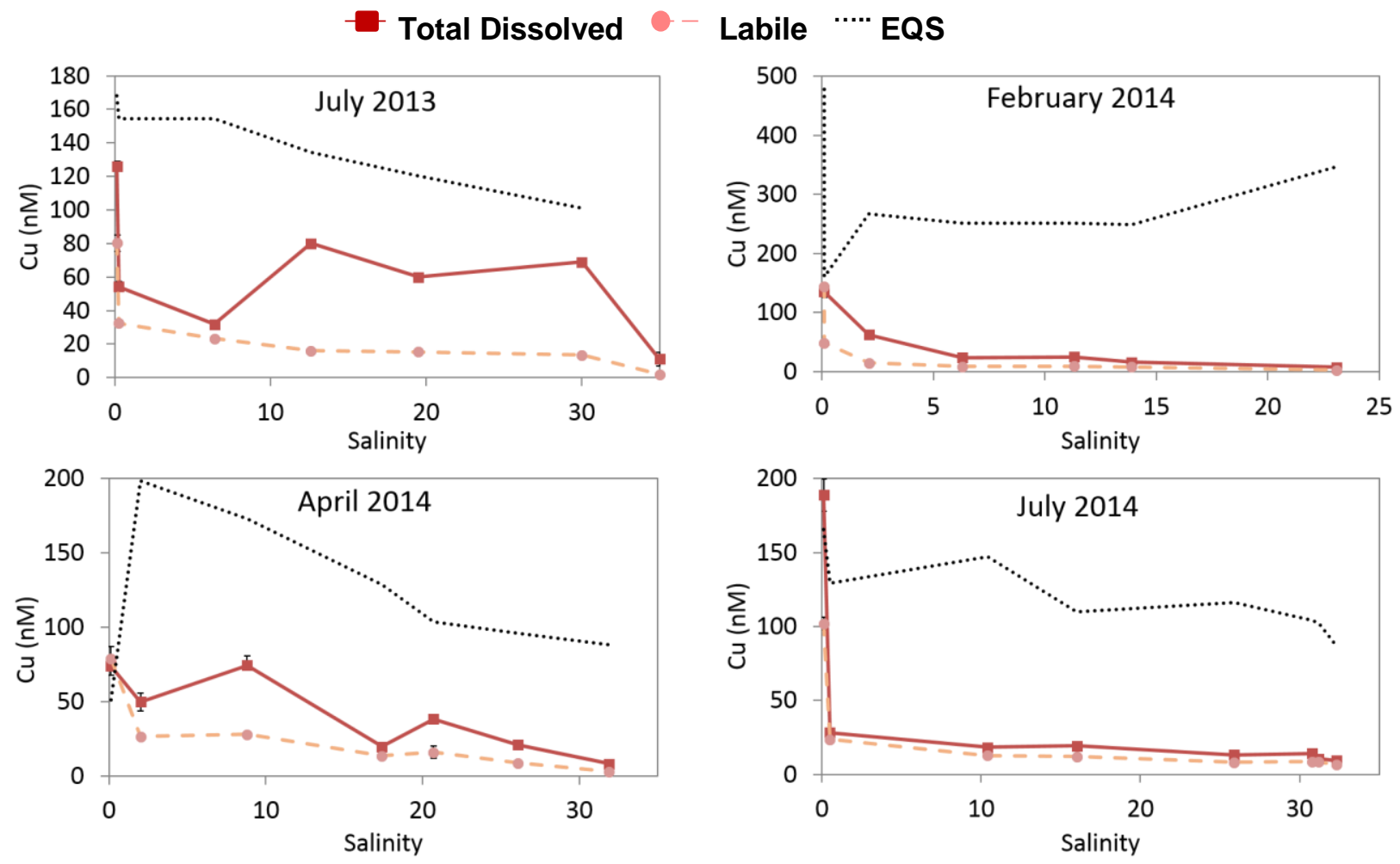

303

304

Figure 3. Total dissolved (dark lines) and labile $\mathrm{Cu}$ (light lines) and new EQS (dotted lines) concentration profiles plotted against salinity observed during the seasonal Tamar transects (note the different scale for February 2014). Error bars represent the range about the mean of duplicate aliquots.

In most cases, the site-specific Cu EQSs for estuarine waters were slightly higher 312 than the previous value $(78 \mathrm{nM} \mathrm{Cu})$, owing to the DOC concentrations determined in 313 the samples being significantly above $83 \mu \mathrm{M}\left(1 \mathrm{mg} \mathrm{C} \mathrm{L}^{-1}\right)$. No exceedance of the EQS 314 was observed within the estuary for any survey, whether comparing with new or previous standards. In terms of BLM development and further consideration of the 
316 bioavailability of the metals however, it is necessary to consider the speciation of $\mathrm{Cu}$

317 in more detail.

319 Compared with total dissolved concentrations, $\left[\mathrm{Cu}_{\mathrm{LAB}}\right.$ ] can better reflect the likely bioavailability of the metal. ${ }^{36}$ Labile $\mathrm{Cu}$ is relatively simple to measure and if it can be shown to provide useable relationships with DOC or other measures of metal complexing ligands then it could have a place within a regulatory framework. Overall, proportions of labile and complexed $\mathrm{Cu}$ determined using the two competitive ligand strengths showed similar patterns along the estuary (Figure 4). There were, however, no strong trends in the \% labile Cu present across the estuary transects, reflecting the complex physico-chemical nature of this estuarine system. This, combined with the presence of varying organic and inorganic ligand concentrations and strength (potentially linked to source), means that strong trends in observed $\mathrm{Cu}$ speciation along the length of an estuary are unlikely. However, some broad observations are possible. Firstly, both the lowest $\left[\mathrm{Cu}_{\mathrm{TD}}\right]$ and $\left[\mathrm{L}_{x}\right]$ are recorded at the seawater end member, reflecting high dilution of any riverine sources and a lack of other significant inputs. As a result, a significant proportion of the $\mathrm{Cu}$ is complexed the mouth of the estuary. The proportion, however, varies between $20 \%$ and $90 \%$ depending on the survey and ligand strength detected. At the highest salinities, in almost all cases there is only marginal organic ligand excess over [CuTD $]$.

It is also clear from the data that the Tamar is not always the main source of organic ligands within the Tamar Estuary. The $\left[\mathrm{Cu}_{\mathrm{TD}}\right]$ is generally high in the river water end member and can exceed the $\left[\mathrm{L}_{x}\right]$, resulting in increased [C $\left.\mathrm{U}_{\mathrm{LAB}}\right]$. Furthermore, there is an obvious input of ligands within the estuary at salinities between 5 and 25 for all surveys. This drives a ligand excess in mid-estuary, leading to percentages of complexed $\mathrm{Cu}$ being greater than $70 \%$ of the total present for all but the April 2014 survey. The HIX and BIX ratios suggest an important humic character of the DOC present in this region (Figure 5), possibly originating from tidal resuspension from the mudflats rich in organic matter, and/or potential inputs from the Tavy and Lynher rivers.

In this work, $\left[\mathrm{Cu}^{2+}\right]$ is a more defined sub-set of $\mathrm{Cu}$ speciation than $\left[\mathrm{Cu}_{\mathrm{LAB}}\right.$ (see equations 1 and 2 in Section S2.1) as determination is undertaken at a predefined competitive ligand strength and reflects only the free metal ion, rather than additional 'labile' forms. Free $\mathrm{Cu}^{2+}$ concentrations in the region of $10^{-12} \mathrm{M}$ were determined (Table S2, Figure S3, not shown owing to the scale), which are typical of those 
measured in other estuaries. ${ }^{8,18,37}$ The $\left[\mathrm{Cu}^{2+}\right]$ determined with any of the three ligand strengths fluctuated throughout the estuary, with no obvious relationship with salinity (contrary to the trend of increasing $\left[\mathrm{Cu}^{2+}\right]$ with salinity reported elsewhere).$^{38}$ This highlights the fact that the complex nature and diverse sources of organic ligands makes it difficult to predict their binding capacity, and thus the potential $\left[\mathrm{Cu}^{2+}\right]$ in the water column, without some form of direct measurement, even when organic carbon is characterised and quantified.
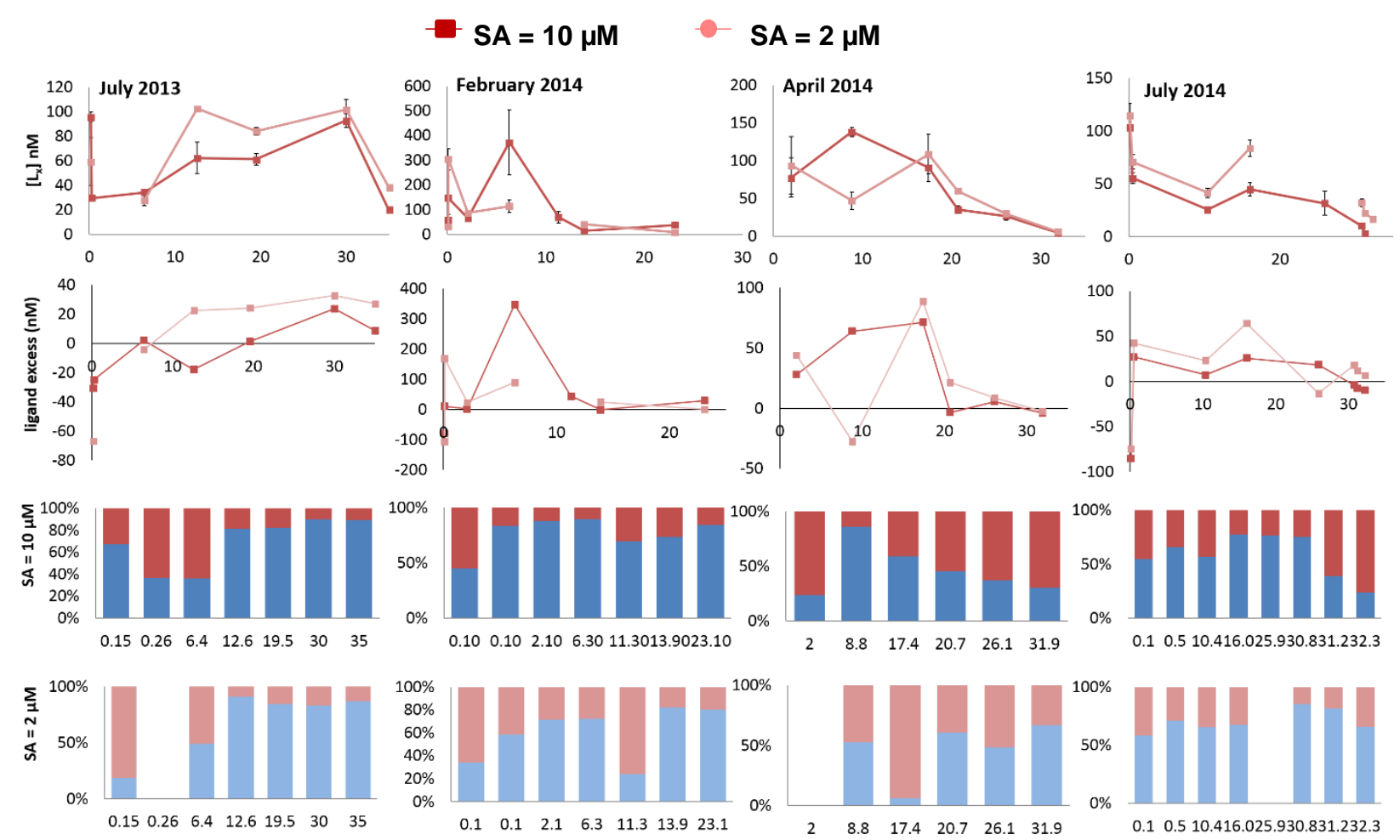

$\square$ \% Cu complexed of TDCu $\square$ \% labile Cu of TDCu

Figure 4. Ligand concentrations $\left(\left[\mathrm{L}_{\mathrm{x}}\right]\right)$, Ligand excess $\left(\left[\mathrm{L}_{\mathrm{x}}\right]-\left[\mathrm{Cu}_{\mathrm{T}}\right]\right)$, and labile and (organically) complexed $\mathrm{Cu}$ as a percentage of total dissolved $\mathrm{Cu}$, for each sampling occasion. Dark red lines represent concentrations determined using $10 \mu \mathrm{M}$ SA, pale red lines $2 \mu \mathrm{M}$ SA. The $x$-axes represent salinity in all cases. Error bars on $\left[L_{x}\right]$ plots represent upper and lower confidence limits calculated from the standard error of the slope of the transformed data. NB. $\left[\mathrm{Cu}^{2+}\right]$ concentrations are $<1 \%$ of $\left[\mathrm{Cu}_{\mathrm{TD}}\right]$ for all samples. 
$373 \quad 3.2$ DOC characterisation and influence on copper speciation

374 A comparison of the data from this study in a plot of $\mathrm{Cu}$ complexing capacity $\left(\left[L_{x}\right]\right)$ versus

375 [DOC] reported in previous studies of other saline waters shows no obvious correlation (data

376 not shown), nor is this the case when separating out weaker ligands ( $\log K<13$ ) likely to be

377 derived from a mixture of autochthonous and allochthonous sources (Figure $5 \mathrm{~A}$ ). However,

378 trends emerge for two of the datasets ${ }^{16,18}$ when isolating the stronger ligands with a Log $K>$

37913 (Figure 5B) that are potentially derived from terrestrial humic sources. ${ }^{18} \mathrm{~A}$ study on the

380 river Scheldt ${ }^{16}$ showed that the ligand concentration can be predicted based on measured

381 DOC and salinity because the source of organic ligands was dominated by a single riverine

382 source. This indicates that for estuaries that feature a strong negative correlation between

383 salinity and DOC, the assumption is reasonable that the DOC is dominated by a riverine

384 source and may therefore be associated with humic and fulvic acids known to complex

385 strongly with $\mathrm{Cu}^{39}$ For the Tamar, no obvious trends were observed between DOC and 386 either $\left[\mathrm{Cu}^{2+}\right]$ or salinity (Figure S4), confirming the complex nature of the interactions 387 between $\mathrm{Cu}$, ligands, sources and concentrations, set against a background of varying 388 physico-chemical conditions within this estuary. Furthermore, DOC concentrations in 389 estuarine waters are typically between 100 and $1000 \mu \mathrm{M},{ }^{17}$ whereas the reported 390 concentrations of copper complexing ligands are typically in the 4 to $400 \mathrm{nM}$ range ${ }^{12}$ i.e. up 391 to 3 orders of magnitude lower, which may explain the observed apparent threshold of 100 $392 \mu \mathrm{M}$ DOC before significant, detectable complexation capacity is measured (Figure $5 \mathrm{~A}$ and 393 B). 
396

400

401 From a modelling perspective the use of DOC alone as a proxy for $\mathrm{Cu}$ complexation and 402 403 404

405 406 407 408 409

\section{Figure 5. Comparison of data from this study with previously reported DOC and Cu complexation capacity in saline waters for ligands with [A]: $\log K<13.0$ and [B]: $\log K>13.0$.}

\section{hence speciation and, more importantly, as a predictor of the most toxic $\left(\mathrm{Cu}^{2+}\right)$ form, is} therefore unlikely to generate sufficiently accurate estimates. The ability to predict $\mathrm{Cu}$ speciation is considered in more detail in the next section.

It is possible to further characterise DOC in water using established 3-D fluorimetry methods which can also help to imply sources of the DOC present and this was explored as a another option for potentially predicting $\mathrm{Cu}$ speciation. The ratios of observed fluorescence peaks can be used to categorise the organic carbon as humic and fulvic, terrestrial or in situ generated material using the humification (HIX) and biological (BIX) indices (A2.5). HIX ratios (Ex260-Em320)/(Ex260-Em460) <4 suggest biological or aquatic bacterial origin, while increasing humic character up to ratios $>16$ show progressively stronger humic character (Figure 6). ${ }^{40}$ For BIX (Ex310$\mathrm{Em} 380) /($ Ex310-Em430) it has been observed that high ratios $(0.8-1.0)$ corresponded
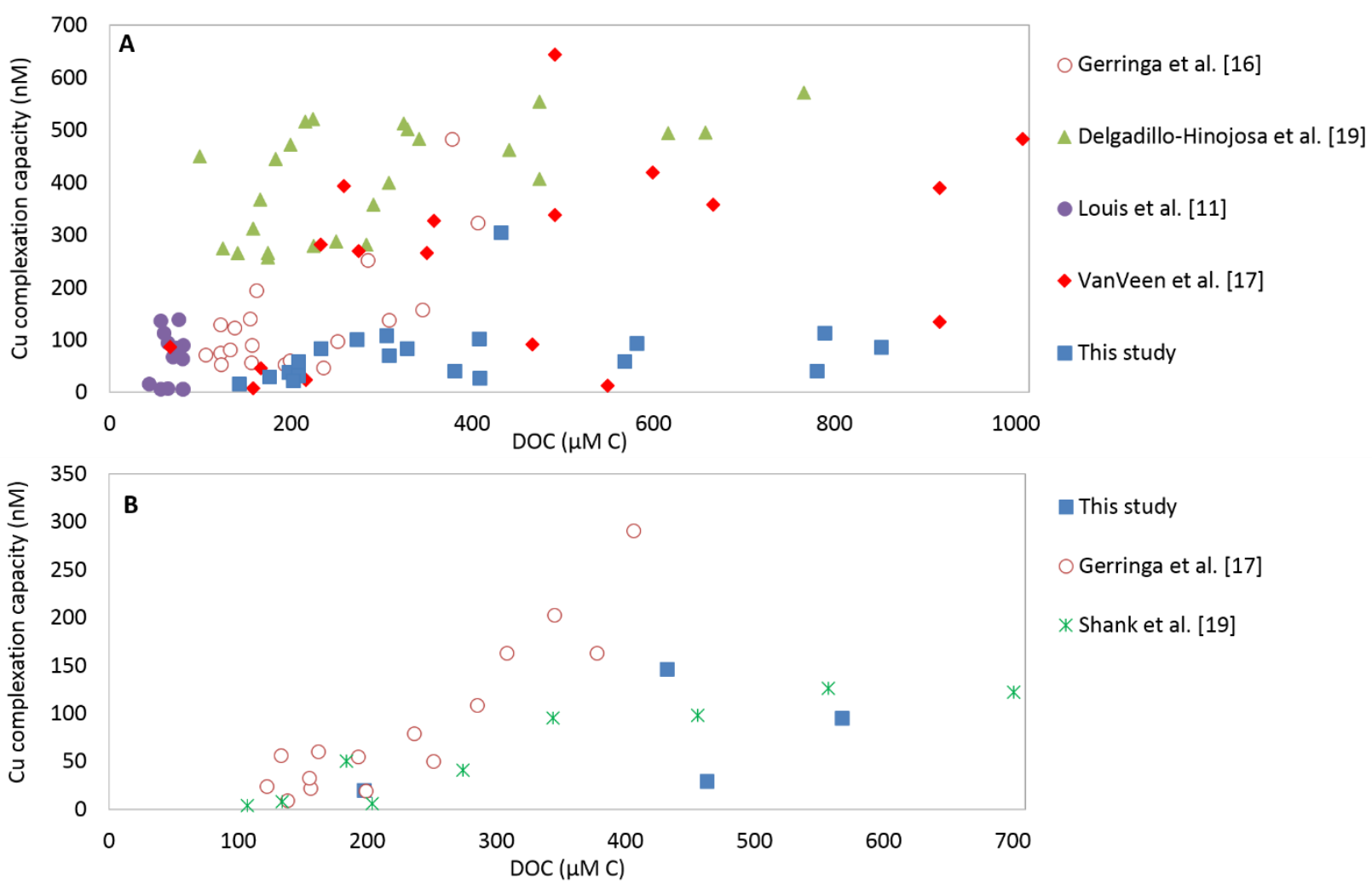
413 
414 to a predominantly autochthonous origin of DOC from recent aquatic and bacterial 415 activity freshly released into water. ${ }^{41}$

416 Fluorescence data for the Tamar surveys showed HIX values generally decreased 417 towards the sea water end member (Figure 6, no data for July 2013). Important humic 418 character was indicated for the fresh water endmember (HIX > 10), while DOC 419 generated by in situ biological processes increased in importance towards the sea 420 water end member (BIX > 0.7). It is likely that the DOC in the lower estuary was at 421 least partially derived from phytoplanktonic activity and/or WwTW effluents. The 422 combined effluent input to the lower estuary from Plymouth works is approximately $72 \times 10^{6}$ $423 \mathrm{~L} \mathrm{~d}^{-1}$, with median DOC concentrations of $12 \mathrm{mg} \mathrm{L}^{-1}$ reported for English effluents, ${ }^{20}$ thus 424 equating to an input of ca. $864 \mathrm{~kg}$ of DOC per day.

425 Upper estuary and riverine HIX indices were > 10 during three surveys, supporting 426 the hypothesis that the DOC was of mainly terrestrial origin, comprising mostly humic 427 and fulvic acids. The BIX index corroborated this, with values increasing towards the 428 sea water end member, demonstrating the autochthonous origin of the DOC present 429 likely to be from primary production during summer months when this signal was 430 strongest at salinities greater than 20.

431 Data from February 2014 appeared to show extreme DOC characteristics within the 432 estuary. Sampling followed a prolonged period of intense rainfall across the SW of 433 England, resulting in widespread flooding. River flows into the Tamar estuary were 434 high enough to suppress salinity at its mouth in Plymouth Sound to 20, where the HIX 435 index of $>20$ indicated the strong terrigenous humic character of the DOC. These 436 unusual estuarine conditions are also reflected in the Cu speciation discussed above 437 (Figures 3 and 4).

438 The data presented above shows that $\left[L_{x}\right]$ was higher at salinities below 20 than 439 towards the seawater end member, reflecting dilution with seawater containing low 440 concentrations of DOC (Figure 4). Concurrently, mostly higher HIX and lower BIX 441 values were observed at salinity $<20$, suggesting the DOC present was derived from 442 riverine sources and largely humic in character (Figure 5).

443 A plot of $\left[\mathrm{L}_{x}\right]$ against $\mathrm{HIX}$ and $\mathrm{BIX}$ shows weak positive and negative correlations, 444 respectively (Figure 6); albeit it should be noted that the range of BIX indices is low 445 for the Tamar Estuary (typically 0.6 to 0.8 ). Highest HIX values were associated with 446 higher complexation capacities, which reflects the strong affinity of $\mathrm{Cu}$ for humic and 447 fulvic acids, ${ }^{18,42}$ which dominate the lower salinity regions in the upper estuary. 
However, this is not necessarily reflected in the observed $\mathrm{Cu}$ speciation (Figures 3 and 4), which would be expected to give rise to less [Cu $\mathrm{CAB}]$ and/or $\left[\mathrm{Cu}^{2+}\right]$ in this region of the estuary owing to complexation (Figures 3, 4 and A3). The presence of a turbidity maximum with commensurate resuspension of contaminated bottom sediment and mine water discharges in the upper estuary containing labile or free metal ion, is therefore likely to be a complicating factor, potentially masking the expectation of lower labile Cu concentration occurring concomitant with a higher HIX index. Based on this dataset, although the indices provide useful information regarding possible sources of ligands, it appears that correlations are not sufficiently robust to improve greatly on the existing use of DOC concentration as a surrogate for Cu complexation characterisation.
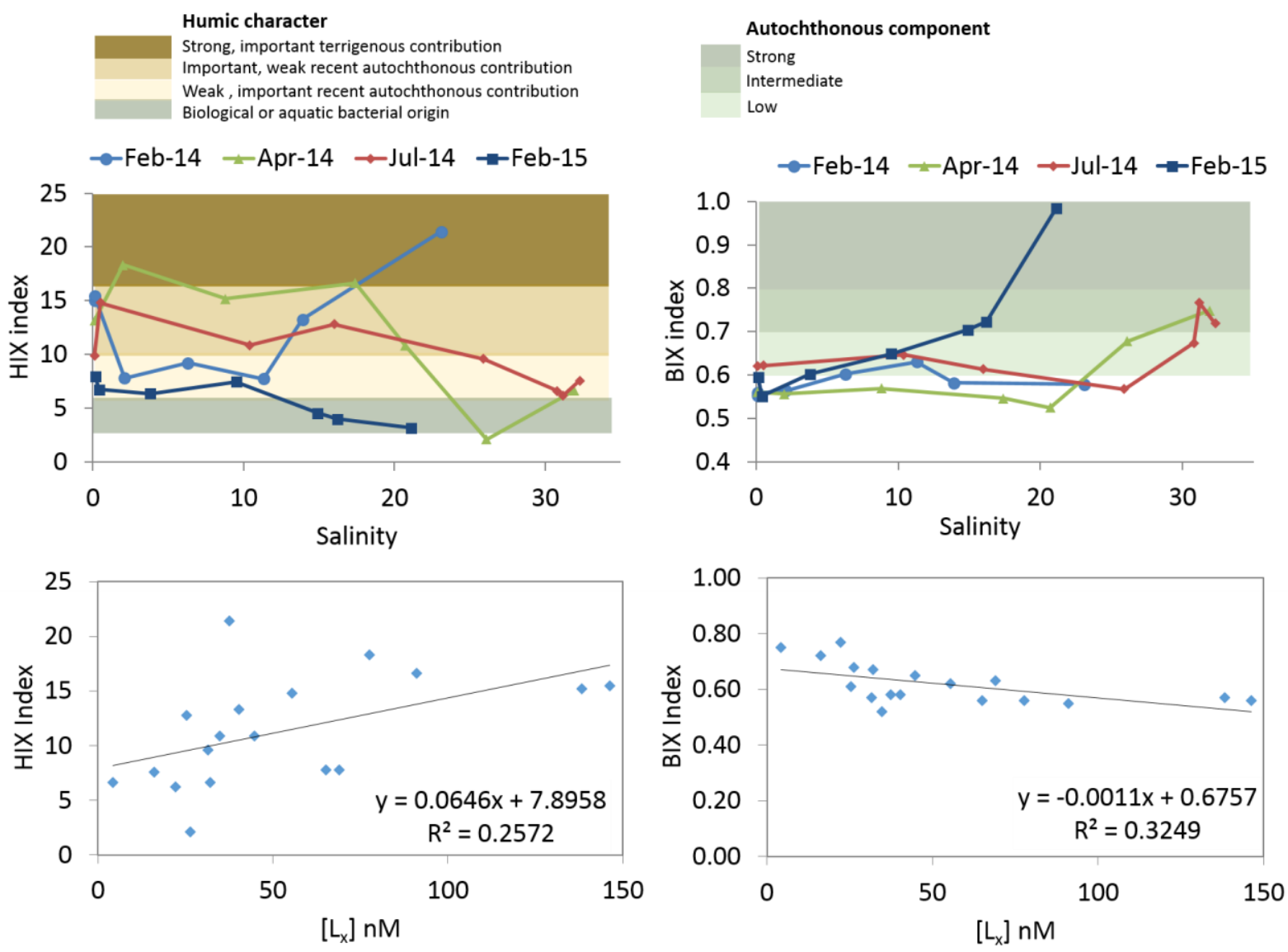

Figure 6. The humification (HIX) and biological (BIX) indices for each seasonal transect against salinity (top) and complexation capacity, $\left[L_{x}\right]$ (bottom). Note dissolved organic carbon characterisation was not carried out for the July 2013 survey. 
467 Models such as the $\mathrm{BLM}^{43}$ and Gill Surface Interaction Model (GSIM) ${ }^{43}$ combine predictions of metal ion activity and organism response to generate site-specific water quality standards taking account of ambient conditions. It should be noted that these models use metal ion activity, not concentration, for calculations. In general, the activity depends on any factor that alters the chemical potential, including concentration, temperature, pressure, interactions between chemical species and electric fields. For saline waters ionic strength can be a significant factor in determining model accuracy ${ }^{44}$ and models typically use the Debye-Hückel or Davies equations to predict species activity. ${ }^{43}$

477 In addition, any chemical speciation model within a BLM needs to incorporate thermodynamic data for organic ligands that are known to be capable of complexing metals in natural waters. Although metal interactions with individual synthetic and some natural organic ligands are well defined, metal - organic ligand interactions in natural waters are complex, variable and more poorly characterised. Given the analytical complexity and time required to determine the complexation capacity and strength of natural organic ligand mixtures, most models apply an algorithm to the DOC concentration to parameterise metal - natural organic ligand interactions. These algorithms are based on the assumption that humic and fulvic acids are the dominant metal complexing ligands in natural waters and estimate their concentrations. Model codes that use such algorithms for DOC corrections, and for which predicted and observed organically bound and/or free metal ion concentrations have been compared, include WHAM VII, ${ }^{45} \mathrm{FIAM}^{46}$ and $\mathrm{VM}^{47}$. However, Figure 1 demonstrates that DOC is often a poor predictor of $\left[\mathrm{L}_{x}\right]$ and possible explanations for this include the assumption of chemical equilibrium in thermodynamic speciation models (unlikely within an estuarine environment) and the very small proportion of metal complexing ligands in the overall DOC pool in natural waters. Some of the challenges associated with predicting free metal ions in saline waters were recently highlighted using the WHAM VII model, which assumes a fixed proportion of measured DOC actively complexes Cu. ${ }^{45}$ The authors showed that approximately $59 \%$ of predictions were within one order of magnitude of the data determined using competitive ligand methods, although the agreement was much better at higher free ion concentrations $\left(>10^{-13} \mathrm{M}\right)$, which are more typically observed in estuarine waters. 
501 To test the NICA-Donnan approach for converting DOC into active Cu binding ligands, the

502 freeware metal speciation programme Visual MINTEQ ${ }^{15}$ was applied to the dataset obtained

503 from the Tamar Estuary and model outputs compared with observed Cu speciation. Using

504 default parameters (Section S3), concentrations for 16 samples from this study across the

505 full salinity range (Table S3) were entered into VM. Two scenarios were run, (i) $\left[L_{x}\right]$ and

$506 \log K_{C u L_{x}}$ obtained via CLE-AdCSV at two detection windows were entered to calculate $\left[\mathrm{Cu}^{2+}\right.$ ]

507 (Figure $7 \mathrm{~A}$ ) and (ii) DOC concentrations were entered to calculate $\left[\mathrm{Cu}^{2+}\right]$ using the NICA-

508 Donnan humic complexation model approach (Figure 6B). The results showed a significant

509 difference in the outputs. Predicted versus measured $\left[\mathrm{pCu}^{2+}\right]$ for scenario (i) showed that the

51016 data points were relatively evenly distributed $\left(r^{2}=0.44\right)$ along the $1: 1$ line, with up to an

511 order of magnitude variation either side and no obvious bias (Figure7A). In contrast,

512 scenario (ii) resulted in a biased prediction of $\left[\mathrm{Cu}^{2+}\right]$, generally under-predicting by as much

513 as two orders of magnitude (Figure 7B), clearly showing that not all of the DOC was active in

514 Cu complexation. Insufficient HIX data did not permit examination as to whether the bias

515 was directly associated with humic character. However, as higher HIX ratios would be

516 expected at low salinity (Figure 5) and there was no systematic variance with salinity

517 (coloured symbols), this estuary is unlikely to show a relationship between humic acids and

518 speciation. Because predictions were generally closer to observations at higher $\left[\mathrm{Cu}^{2+}\right]$, either

519 modelling approach can more accurately predict $\left[\mathrm{Cu}^{2+}\right]$ when the risk of toxic effects

520 occurring is greater. 

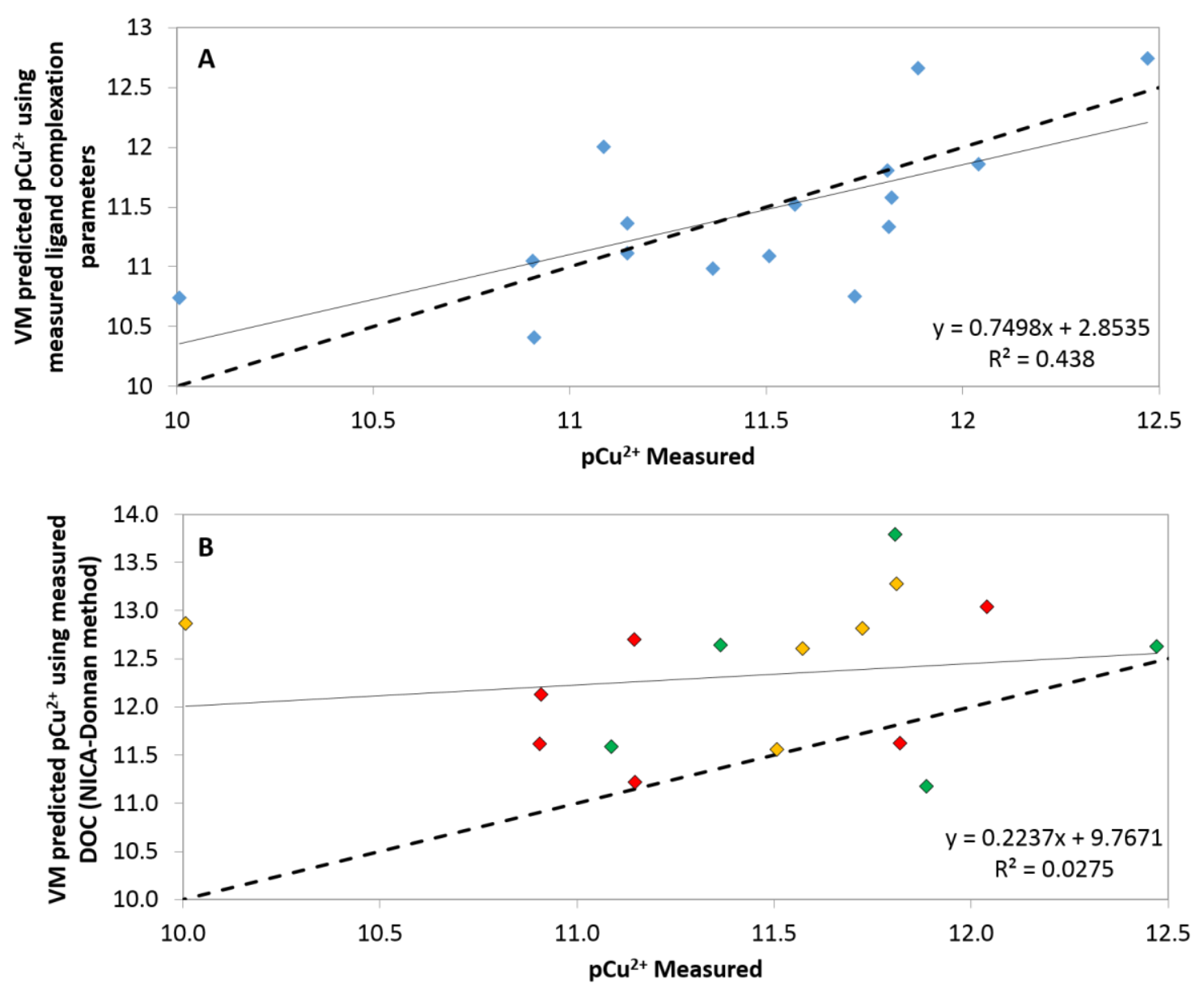

522

523

524

525

526

527

528

529

530 The under-prediction of $\left[\mathrm{Cu}^{2+}\right]$ present in estuarine waters would be a concern, as regulators and practitioners rely on models to provide conservative estimates to ensure environmental protection. Under-predicting the most toxic fraction of $\mathrm{Cu}$ cannot be considered precautionary and may not provide adequate protection to vulnerable aquatic species.

534 These results show that VM or similar equilibrium speciation codes can be used to predict free metal ion concentrations with adequate certainty, given sufficient $\mathrm{Cu}$ ligand data. Obtained results can be used in conjunction with data on ecotoxicological
Figure 7. Measured versus predicted (using Visual Minteq) $\left[\mathrm{Cu}^{2+}\right]$ concentration plotted as $\mathrm{pCu}^{2+}\left(-\log _{10}\right.$ of the molar concentration) with 1:1 line included (dashed line). Solid lines represent the linear least squares regression of the data. [A] using ligands measured as part of this work and [B] using VM ligands generated using measured DOC and the Nica-Donnan method (Green, amber and red symbols $=$ salinity $<10 ; 10-20$ and $>20$ respectively). endpoints to assist in developing BLMs. This approach may help to eliminate the uncertainties observed in EC50 values plotted against DOC (Figure S2). The priority 
539 is to characterise a set of organic ligands within individual estuarine scenarios where

540 the sources are potentially very varied and quite different from riverine situations.

542 From a regulatory perspective, estuarine dissolved $\mathrm{Cu}$ concentrations were lower than the 543 new DOC-corrected Cu EQS; however the relevance of DOC as an accurate proxy for Cu 544 speciation (and hence potential toxicity) throughout an estuarine salinity profile is 545 questionable, as discussed in section 3.3. The Tamar data shows no direct relationship 546 between complexation capacity or $\mathrm{Cu}$ speciation and DOC concentration, and metal 547 complexation trends are not related to the source and characteristics of the Cu complexing 548 ligands. The lack of relationships between these parameters in the Tamar Estuary is 549 probably the result of a number of factors including ligand source and strength, resuspension 550 and particulate sorption chemistry, chemical precipitation reactions and colloidal interactions. 551 The Tamar Estuary is not likely to be unique in this complexity and in addition, many 552 estuaries contain a continuum of ligands with strengths that vary from very weak to very 553 strong, at variable concentrations and which also exhibit temporal variability. Consequently, 554 attributing a single factor to explain observed metal speciation may not be adequate to 555 provide regulators with sufficiently accurate speciation predictions.

556 Even with this degree of complex physico-chemical interactions, and accepting that 557 speciation models are based on an assumption of chemical equilibrium, this research has 558 shown that it is possible to predict free metal concentrations within an order of magnitude of measured concentrations by using freely available chemical speciation software and inputting determined major ion concentrations and $\mathrm{Cu}$ ligand data (concentration and $\log K_{C u L_{x}}$ values). In contrast, using the NICA-Donnan complexation model to predict $\mathrm{Cu}$ speciation based on inputting DOC concentrations generated a bias in $\left[\mathrm{Cu}^{2+}\right.$ predictions which overestimated the free metal ion concentration for 14 out 16 samples across all salinities by up to almost two orders of magnitude. It should be noted that as part of the Nica-Donnan assumptions, the DOM:DOC ratio is generated from Swedish lakes and rivers samples dominated by humic and fulvic acids ${ }^{48}$ which may not be reflective of sources of DOC in estuaries for the reasons discussed above. The data presented here show that, although DOC is broadly indicative of Cu complexation, it cannot be relied on as a basis for predicting free $\mathrm{Cu}$ concentrations in estuarine waters. Consequently, the use of DOC concentration in setting EQS should be considered as an interim step, with future BLM development for estuarine waters needing to take into account more detailed Cu speciation.

572 Further data are required regarding the characterisation of organic ligands and their sources, 573 matched to observed ecotoxicological outcomes, to generate a robust BLM upon which 574 future environmental legislation and robust environmental quality standards can be based. 
577 This work was co-funded by the European Copper Institute, International Zinc

578 Association and Plymouth University. With thanks to the Plymouth University

579 laboratory technical staff, constructive comments by funding partners, David Rushby

580 for skippering the boat along the Tamar, Dr. Aga Kosinska and David Deruytter for assistance in the laboratory and Dr. Alan Tappin for DOC analysis.

582

\section{Supporting Information.}

584 Provides details:

585 New vs previous EQS for $\mathrm{Cu}$ in estuarine and coastal waters

586 Mussel toxicity data vs DOC

587

588

589

590

591

592

\section{References}

Free Cu figures vs salinity and vs DOC for two different ligand strengths Details of sampling protocol and detailed analytical methodology.

Further details of the VM model

Tabulated raw data for the Tamar surveys and tabulated VM input data

1. Reeder, R. J.; Schoonen, M. A.; Lanzirotti, A., Metal speciation and its role in bioaccessibility and bioavailability. Rev. Mineral. and Geochem. 2006, 64, (1), 59-113.

2. Caussy, D.; Gochfeld, M.; Gurzau, E.; Neagu, C.; Ruedel, H., Lessons from case studies of metals: investigating exposure, bioavailability, and risk. Ecotox. and Environ. Safety 2003, 56, (1), 45-51.

3. Di Toro, D. M.; Allen, H. E.; Bergman, H. L.; Meyer, J. S.; Paquin, P. R.; Santore, R. C., Biotic ligand model of the acute toxicity of metals. 1. Technical Basis. Environ. Toxicol. and Chem. 2001, 20, (10), 2383-2396.

4. Heijerick, D. G.; De Schamphelaere, K. A. C.; Janssen, C. R., Predicting acute zinc toxicity for Daphnia magna as a function of key water chemistry characteristics: Development and validation of a biotic ligand model. Environ. Toxicol. and Chem. 2002, 21, (6), 1309-1315.

5. Gillis, P. L.; McGeer, J. C.; Mackie, G. L.; Wilkie, M. P.; Ackerman, J. D., The effect of natural dissolved organic carbon on the acute toxicity of copper to larval freshwater mussels (glochidia). Environ. Toxicol. and Chem. 2010, 29, (11), 2519-2528.

6. USEPA Draft Update of Ambient Water Quality Criteria for Copper; 2003.

7. USEPA United States Environmental Protection Agency, National

Recommended Water Quality Criteria - Aquatic Life Criteria Table; https://www.epa.gov/wqc/national-recommended-water-quality-criteria-aquatic-lifecriteria-table, 2016.

8. Chadwick, D. B.; Rivera Duarte I.; Rosen G., Wang P.F., Santore R.C., Ryan A.C., Paquin P.R., Hafner S.D. and Choi W. Demonstration of an integrated compliance model for predicting copper fate and effects in DoD harbors; Space And Naval Warfare Systems Center Pacific: San Diego CA, 2008.

\section{USEPA United States Environmental Protection Agency, National}

Recommended Water Quality Criteria - Aquatic Life Criteria Table; https://www.epa.gov/wqc/national-recommended-water-quality-criteria-aquaticlife-criteria-table, 2016.

10. Louis, Y.; Garnier, C.; Lenoble, V.; Mounier, S.; Cukrov, N.; Omanović, D.; 
653

654

655

656

657

658

659

660

661

662

663

664

665

666

667

668

669

670

671

672

673

674

675

676

677

678

679

complexation in water column of the stratified Krka River estuary (Croatia). Mar. Chem. 2009, 114, (3-4), 110-119.

11. Van Veen, E.; Gardner, M. J.; Comber, S. D. W., Temporal variation of copper and zinc complexation capacity in the Humber estuary. J. Environ. Mon. 2001, 3, (3), 322-323.

12. Maycock, D., Graham; Peters, A. Proposed EQS for Water Framework Directive Annex VIII substances: copper (saltwater) (For consultation); Edinburgh, 2012.

13. Arnold, W. R.; Cotsifas, J. S.; Ogle, R. S.; DePalma, S. G. S.; Smith, D. S., A comparison of the copper sensitivity of six invertebrate species in ambient salt water of varying dissolved organic matter concentrations. Environ. Toxicol. and Chem. 2010, 29, (2), 311-319.

14. Sarathy, V.; Allen, H. E., Copper complexation by dissolved organic matter from surface water and wastewater effluent. Ecotox. and Environ. Safety 2005, 61, (3), 337344.

15. Gustafsson, J., Visual MINTEQ version 3.1. Department of Land and Water Resources Engineering, Royal Institute of Technology, Stockholm, Sweden 2013.

16. Gerringa, L. J. A.; Hummel, H.; Moerdijk-Poortvliet, T. C. W., Relations between free copper and salinity, dissolved and particulate organic carbon in the Oosterschelde and Westerschelde, Netherlands. J. of Sea Res. 1998, 40, (3-4), 193-203.

17. Van Veen, E.; Burton, N.; Comber, S.; Gardner, M., Speciation of copper in sewage effluents and its toxicity to Daphnia magna. Environ. Toxicol. and Chem. 2002, 21, (2), 275-280.

18. Shank, G. C.; Skrabal, S. A.; Whitehead, R. F.; Avery, G. B.; Kieber, R. J., River discharge of strong Cu-complexing ligands to South Atlantic Bight waters. Mar. Chem. 2004, 88, (1-2), 41-51.

19. Delgadillo-Hinojosa, F.; Zirino, A.; Nasci, C., Copper complexation capacity in surface waters of the Venice Lagoon. Mar. Environ. Res. 2008, 66, (4), 404-411.

20. Gardner, M.; Comber, S.; Scrimshaw, M. D.; Cartmell, E.; Lester, J.; Ellor, B., The significance of hazardous chemicals in wastewater treatment works effluents. Sci. Tot. Environ. 2012, 437, (0), 363-372.

21. Constantino, C. The effect of sewage effluent on trace metal speciation: Implications for the biotic ligand model approach. Brunel University, Uxbridge, 2012.

22. Andrade, S.; Pulido, M. J.; Correa, J. A., The effect of organic ligands exuded by intertidal seaweeds on copper complexation. Chemosphere 2010, 78, (4), 397-401.

23. Langston, W. J.; Chesman, B. S.; Burt, G. R.; Hawkins, S. J.; Readman, J.; Worsfold, P., Characterisation of the South West European Marine Sites. Plymouth Sound and Estuaries CSAC, SPA. Occasional Publications. 2003, Mar. Biol. Assoc. UK (9) $202 p$.

24. Mighanetara, K.; Braungardt, C. B.; Rieuwerts, J. S.; Azizi, F., Contaminant fluxes from point and diffuse sources from abandoned mines in the River Tamar catchment, UK. J. Geochem. Explor. 2009, 100, (2-3), 116-124.

25. Miller, A. E. J., Seasonal Investigations of Dissolved Organic Carbon Dynamics in the Tamar Estuary, U.K. Est. Coast. Shelf Sci. 1999, 49, (6), 891-908.

26. Trigueros, J. M.; Orive, E., Tidally driven distribution of phytoplankton blooms in a shallow, macrotidal estuary. J. Plank. Res. 2000, 22, (5), 969-986.

27. Rule, K. L.; Comber, S. D. W.; Ross, D.; Thornton, A.; Makropoulos, C. K.; Rautiu, R., Sources of priority substances entering an urban wastewater catchmenttrace organic chemicals. Chemosphere 2006, 63, (4), 581-591.

28. Ružić, I., Theoretical aspects of the direct titration of natural waters and its information yield for trace metal speciation. Anal. Chim. Acta 1982, 140, (1), 99-113.

29. van den Berg, C. M. G., Determination of copper complexation with natural organic ligands in seawater by equilibration with $\mathrm{MnO}_{2}$. Theory. Mar. Chem. 1982, 11, (4), 307-322.

30. Badr, E.-S. A.; Achterberg, E. P.; Tappin, A. D.; Hill, S. J.; Braungardt, C. B., Determination of dissolved organic nitrogen in natural waters using high-temperature catalytic oxidation. TrAC Trends in Anal. Chem. 2003, 22, (11), 819-827. 
692

693

694

695

696

697

698

699

700

701

702

703

704

705

706

707

708

709

710

711

712

713

714

715

716

717

718

719

720

721

722

723

724

725

726

727

728

729

730

731

732

733

734

735

736

737

31. van den Berg, C. M. G.; Kramer, J. R., Determination of complexing capacities of ligands in natural waters and conditional stability constants of the copper complexes by means of manganese dioxide. Anal. Chim. Acta 1979, 106, (1), 113-120.

32. Environment Agency (2016) Environmental Agency Water Quality archive (WIMS) available at http://environment.data.gov.uk/water-quality/view/landing; accessed 18 March 2016.

33. Stumm, W.; Morgan, J. J., Aquatic chemistry: chemical equilibria and rates in natural waters. 3rd ed.; John Wiley and Sons: 1995; Vol. 126.

34. Howell, K. A.; Achterberg, E. P.; Tappin, A. D.; Worsfold, P. J., Colloidal Metals in the Tamar Estuary and their Influence on Metal Fractionation by Membrane Filtration. Environ. Chem. 2006, 3, (3), 199-207.

35. Grabemann, I.; Uncles, R. J.; Krause, G.; Stephens, J. A., Behaviour of Turbidity Maxima in the Tamar (U.K.) and Weser (F.R.G.) Estuaries. Est. Coast.Shelf Sci. 1997, 45, (2), 235-246.

36. Howard, A. G.; Apte, S. C.; Comber, S. D. W.; Morris, R. J., Biogeochemical control of the summer distribution and speciation of arsenic in the Tamar estuary. Est. Coast. Shelf Sci. 1988, 27, (4), 427-443.

35. van den Berg, C. M. G.; Khan, S. H.; Daly, P. J.; Riley, J. P.; Turner, D. R., An electrochemical study of $\mathrm{Ni}, \mathrm{Sb}, \mathrm{Se}, \mathrm{Sn}, \mathrm{U}$ and $\mathrm{V}$ in the estuary of the Tamar. Est. Coast. Shelf Sci. 1991, 33, (3), 309-322.

36. Stauber, J. L.; Andrade, S.; Ramirez, M.; Adams, M.; Correa, J. A., Copper bioavailability in a coastal environment of Northern Chile: Comparison of bioassay and analytical speciation approaches. Mar. Poll. Bull. 2005, 50, (11), 1363-1372.

37. Tang, D.; Warnken, K. W. and Santschi, P. H., T, Organic complexation of copper in surface waters of Galveston Bay. Limnol Oceanogr 2001, (46), 321-330.

38. van den Berg, C. M. G.; Nimmo, M.; Daly, P.; Turner, D. R., Effects of the detection window on the determination of organic copper speciation in estuarine waters. Anal. Chim. Acta 1990, 232, (0), 149-159.

39. Paquin, P.R.; Gorsuch, J.W.; Apte, S.; Batley, G.E.; Bowles, K.C.; Campbell, P.G.C.; Delos, C.G.; Di Toro, D.M.; Dwyer, R.L.; Galvez, F.; Gensemer, R.W.; Goss, G.G.; Hogstrand, C.; Janssen, C.R.; McGeer, J.C.; Naddy, R.B.; Playle, R.C.; Santore, R.C.; Schneider, U.; Stubblefield, W.A.; Wood, C.M.; Wu, K.B., The biotic ligand model: a historical overview. Comp. Biochem. \& Physiol. Part C: Toxicol. \& Pharmacol. 2002, 133, (1-2), 3-35.

40. Zsolnay, Á., Dissolved organic matter: artefacts, definitions, and functions. Geoderma 2003, 113, (3-4), 187-209.

41. Huguet, A.; Vacher, L.; Relexans, S.; Saubusse, S.; Froidefond, J. M.; Parlanti, E., Properties of fluorescent dissolved organic matter in the Gironde Estuary. Org. Geochem. 2009, 40, (6), 706-719.

42. Abualhaija, M. M.; Whitby, H.; van den Berg, C. M. G., Competition between copper and iron for humic ligands in estuarine waters. Mar. Chem. 2015, 172, 46-56.

43. Pagenkopf, G. K., Gill surface interaction model for trace-metal toxicity to fishes: role of complexation, $\mathrm{pH}$, and water hardness. Environ. Sci.\& Technol. 1983, 17, (6), 342-347.

44. Jardim, W.F. and Allen, H.E., 1984. Measurement of copper complexation by naturally occurring ligands. In: C.J.M. Kramer and J.C. Duinker (Editors), Complexation of Trace Metals in Natural Waters. Nijhoff/Junk, The Hague, The Netherlands, pp. 115.

45. Stockdale, A.; Tipping, E.; Lofts, S., Dissolved trace metal speciation in estuarine and coastal waters: Comparison of WHAM/Model VII predictions with analytical results. Environ. Toxicol. and Chem. 2015, 34, (1), 53-63.

46. Hudson, R. J. M., Trace metal uptake, natural organic matter, and the free-ion model. J. Phycology 2005, 41, (1), 1-4.

47. Unsworth, E. R.; Warnken, K. W.; Zhang, H.; Davison, W.; Black, F.; Buffle, J.; Cao, J.; Cleven, R.; Galceran, J.; Gunkel, P.; Kalis, E.; Kistler, D.; van Leeuwen, H. P.; Martin, M.; Noel, S.; Nur, Y.; Odzak, N.; Puy, J.; van Riemsdijk, W. H.; Sigg, L.; Temminghoff, E.; Tercier-Waeber, M. L.; Toepperwien, S.; Town, R. M.; Weng, L. P.; Xue, H. B., Model predictions of metal speciation in freshwaters compared to measurements by in situ techniques. Environ. Sci. \& Technol. 2006, 40, (6), 1942-1949. 
48 Sjöstedt, C.S., Gustafsson, J.P., Köhler, S.J., Chemical equilibrium modeling of 739 organic acids, $\mathrm{pH}$, aluminum, and iron in Swedish surface waters. Environ. Sci. Technol. $740 \quad 2010,44,8587-8593$. 